\title{
MEMBANGUN MODEL PENYEBARAN PENYAKIT AKIBAT ASAP KEBAKARAN HUTAN
}

\author{
B. Kurniawan ${ }^{1}$, R. Ratianingsih², dan Hajar $^{3}$ \\ 1,2,3Program Studi Matematika Jurusan Matematika FMIPA Universitas Tadulako \\ Jalan Soekarno-Hatta Km. 09 Tondo, Palu 94118, Indonesia. \\ 1Kurniawanbilly31@gmail.com, 2Ratianigsih@yahoo.com, 3hajar.20049@yahoo.com
}

\section{ABSTRACT}

Forest fires impact a very serious problem because it could cause health problem, especially respiratory disease such as (ISPA), Asthma and Bronchitis. The study of the health disorders is conducted by consider mathematicaly the spread of disease due to forest fires smoke. The model is constructed by devide the human population into six subpopulations, that is vulnerable $S(t)$, exposed $E(t)$, Asthma infected $A(t)$, Bronchitis infected $B(t)$ and recovered $R(t)$. The governed model is analyted at every critical points using Routh-Hurwitz method. The results gives two critical points that describe a free disease conditions $\left(T_{1}\right)$ and an endemic conditions $\left(T_{2}\right)$. A stabil $\left(T_{1}\right)$ is occured if $R_{0 H}<1$ and $R_{0 B}<1$ where the threshold point of the stability is expressed as $R_{0 H}=$ $\frac{\beta_{1} \alpha \rho_{1}}{\mu\left(\rho_{1}+\mu+\rho_{2}\right)\left(\gamma_{1}+\gamma_{2}+\delta_{1}+\mu+v_{1}\right)}$ and $R_{0 B}=\frac{\beta_{2} \alpha}{\mu\left(\mu+v_{3}+\delta_{2}\right)}$. Endemic conditions $\left(T_{2}\right)$ will be asymptotically stable when $R_{0 B}{ }^{*}<$ $R_{0 B}<1$ and $\frac{\beta_{1}}{\beta_{2}}<\frac{\left(\gamma_{1}+\gamma_{2}+\delta_{1}+v_{1}\right)}{\left(\mu+v_{3}+\delta_{2}\right)}$ with $R_{0 B}{ }^{*}=\frac{\mu^{2}+\left(v_{3}+\delta_{2}+\tau\right) \mu+\tau v_{3}}{\mu^{2}+\left(v_{3}+\delta_{2}+\tau+1\right) \mu+\left(v_{3}+1\right) \tau}$. The condition of free disease of forest fires is occured in a long time period, while the endemic conditions is occurred in a short time period. It could be interpreted that the disease spread due to the forest fires smoke is not easy to overcome.

\section{Keywords : Asthma, Bronchitis, Floating Point Stability, ISPA, Stability, Routh-Hurwitz.}

\section{ABSTRAK}

Dampak kebakaran hutan menimbulkan masalah yang sangat serius karena dapat mengakibatkan gangguan kesehatan terutama penyakit (ISPA), Asma dan Bronchitis. Kajian terhadap gangguan kesehatan tersebut dalam penelitian ini ditinjau melalui model penyebaran penyakit akibat asap kebakaran hutan. Dalam kontruksi model, populasi manusia dibagi menjadi 6 subpopulasi, yaitu Subpopulasi manusia rentan $S(t)$, subpopulasi exposed $E(t)$, subpopulasi terinfeksi ISPA $H(t)$, subpopulasi terinfeksi Asma $A(t)$, subpopulasi terinfeksi Bronchitis $B(t)$ dan subpopulasi sembuh $R(t)$. Model yang dihasilkan tersebut dianalisa kestabilannya di setiap titik kritis dengan metode Routh-Hurwitz. Dari hasil penelitian didapatkan 2 titik kritis yang menggambarkan kondisi bebas penyakit $\left(T_{1}\right)$ dan kondisi endemik $\left(T_{2}\right)$, dimana $T_{1}$ stabil jika $R_{0 H}<1$ dan $R_{0 B}<1$ dengan batas ambang kestabilan yang diekspresikan sebagai $R_{0 H}=\frac{\beta_{1} \alpha \rho_{1}}{\mu\left(\rho_{1}+\mu+\rho_{2}\right)\left(\gamma_{1}+\gamma_{2}+\delta_{1}+\mu+v_{1}\right)}$ dan $R_{0 B}=\frac{\beta_{2} \alpha}{\mu\left(\mu+v_{3}+\delta_{2}\right)}$. Kondisi endemik $\left(T_{2}\right)$ akan stabil asimtotik saat $R_{0 B}{ }^{*}<R_{0 B}<1$ dan $\frac{\beta_{1}}{\beta_{2}}<\frac{\left(\gamma_{1}+\gamma_{2}+\delta_{1}+v_{1}\right)}{\left(\mu+v_{3}+\delta_{2}\right)} \quad$ dengan $R_{0 B}{ }^{*}=$ $\frac{\mu^{2}+\left(v_{3}+\delta_{2}+\tau\right) \mu+\tau v_{3}}{\mu^{2}+\left(v_{3}+\delta_{2}+\tau+1\right) \mu+\left(v_{3}+1\right) \tau}$. Sedangkan kondisi bebas penyakit yang menggambarkan terbebasnya populasi dari asap kebakaran hutan akan tercapai dalam waktu yang sangat lama. Sedangkan kondisi endemik tercapai dalam waktu yang singkat. Hal ini menjelaskan bahwa penyakit akibat asap kebakaran hutan tidak mudah untuk diatasi.

Kata Kunci : Asma, Batas Ambang Kestabilan, Bronchitis, ISPA, Kestabilan, Routh-Hurwitz 


\section{PEDAHULUAN}

\subsection{Latar Belakang}

Kebakaran hutan di Indonesia berdampak hingga regional Asia Tenggara yang berpengaruh terhadap berbagai sektor kehidupan seperti gangguan aktivitas kehidupan sehari-hari, hambatan transportasi, kerusakan ekologis, penurunan pariwisata, dampak politik, ekonomi dan gangguan kesehatan [1]. World Health Organization (WHO) memperkirakan sekitar 20 juta orang Indonesia telah dilingkupi asap kebakaran hutan yang mengakibatkan berbagai gangguan paru-paru dan sistem pernapasan [1].

Asap yang timbul dari kebakaran hutan memberikan banyak dampak negatif yang dapat mengganggu kesehatan masyarakat terutama masyarakat miskin, lanjut usia, ibu hamil dan anak balita seperti infeksi saluran pernafasan. Hal ini dikarenakan asap kebakaran hutan mengandung bahan kimia seperti komponen gas seperti sulfur dioksida (SO2), karbon monoksida (CO), formaldehid, akrelein, benzen, nitrogen oksida (NOx) dan ozon (O3) ${ }^{[1]}$. Ada banyak penyakit yang disebabkan oleh kandungan bahan kimia yang terdapat pada asap kebakaran yaitu Infeksi Saluran Pernafasan Akut (ISPA) dan bronchitis yang dapat menyebabkan kematian dini ${ }^{[2]}$.

Akibat asap tersebut orang yang rentan akan terinfeksi penyakit ISPA dan bronchitis. Penyakit ISPA di klasifikasikan menjadi 2 bagian yaitu ispa bagian atas dan ispa bagian bawah. ISPA bagian atas akan menyerang struktur-struktur saluran nafas disebelah atas laring. Lama kelamaan asap yang dihirup akan menyebabkan ISPA bagian bawah dan merusak struktur saluran pernafasan mulai laring sampai dengan alveoli atau paru-paru. Hal ini yang menyebabkan penyakit asma dan penyakit bronchitis menjadi akut atau kronik bahkan dapat menyebabkan kematian. Orang yang terkena penyakit ISPA dan bronchitis dapat disembuhkan jika yang terinfeksi dirawat di rumah sakit atau di berikan obat. Sedangkan penyakit asma tidak dapat disembuhkan melainkan penyakit asma dapat dikontrol dengan menggunakan obat.

ISPA merupakan salah satu penyebab kematian tersering pada anak di negara berkembang. Setiap anak balita diperkirakan mengalami 3-6 episode ISPA setiap tahunnya dan proporsi kematian yang disebabkan ISPA mencakup 20-30\% [8]. Diperkirakan pada tahun 2003 kasus kesakitan balita akibat ISPA sebanyak lima dari 1000 balita [6].

Asma juga merupakan penyakit yang menjadi masalah kesehatan masyarakat di hampir semua Negara di dunia. Faktor lingkungan yang berperan sebagai faktor pencetus serangan/eksaserbasi dan menyebabkan gejala-gejala asma menetap yaitu: alergen di dalam dan di luar ruangan, polusi udara di dalam dan di luar ruangan, infeksi saluran pernapasan, exercise dan hiperventilasi [3]. Terdapat 4.487 kematian akibat penyakit asma atau sekitar 1,6 
per 100.000 populasi, sedangkan didapatkan juga sebanyak 223 kematian anak usia 0-17 tahun atau 0,3 per 100.000 populasi [5].

Bronchitis kronik merupakan penyakit saluran napas yang sering didapat di masyarakat.Infeksi saluran nafas merupakan masalah klinis yang sering dijumpai pada penderita bronchitis kronik yang dapat memperberat penyakitnya ${ }^{[7]}$. Bronchitis kronik adalah batuk berdahak yang terjadi selama sedikitnya 3 bulan dalam setahun untuk 2 tahun berturutturut ${ }^{[4]}$. Bersamaan dengan empisema dan asma, bronchitis kronik menduduki tempat ke- 6 dari 10 penyebab kematian di Indonesia dengan proporsi sebesar $5,6 \%$ dari semua kematian [9].

Penelitian ini akan mengkaji penyebaran penyakit yang disebabkan oleh asap kebakaran hutan yang direpresentasikan dalam sebuah model matematika. Model penyebaran ini dikonstruksi berdasarkan model Susceptible Exposed Infected Recovered (SEIR). Model SEIR dibangun akan dikaji kestabilannya melalui bilangan reproduksi dasar untuk mengetahui penyebaran penyakit yang disebabkan oleh asap kebakaran hutan dalam suatu populasi.

\subsection{Batasan Penelitian}

Adapun batasan penelitian ini hanya pada penyakit yang timbul akibat asap kebakaran hutan pada penyakit ISPA, Asma dan Bronchitis pada manusia.

\section{METODE PENELITIAN}

Penelitian ini bersifat kajian kualitatif terhadap SPD non linear dengan menggunakan metode linearisasi. SPD yang dikaji dibangun atas variabel-variabel $S(t), E(t), H(t), A(t), B(t), R(t)$, adapun langkah kajian pada setiap kombinasi adalah:

a. Mencari titik kritis dari SPD yang telah dibangun dengan meninjau persamaan pembangun pada kondisi stagnan, selanjutnya dievaluasi menggunakan matriks Jacobian.

b. Mencari bilangan reproduksi dasar dengan Next Generation Matrix

c. Menganalisis kestabilan sistem dengan cara melihat tanda akar-akar polinomial karakteristik dari matriks Jacobian yang telah dievaluasi pada titik kritis. Karena polinomial karakteristik dari matriks Jacobian yang diperoleh berderajat tinggi, maka digunakan bantuan kriteria Routh-Hurwitz untuk mempermudahnya.

d. Melakukan simulasi dengan memasukkan nilai-nilai parameter yang telah ditentukan ke dalam SPD. 


\section{HASIL DAN PEMBAHASAN}

\subsection{Model Matematika Penyebaran penyakit Akibat Asap Kebakaran Hutan}

Kontruksi model yang menggambarkan penyebaran penyakit akibat asap kebakaran hutan pada populasi manusia digambarkan sebagai berikut:

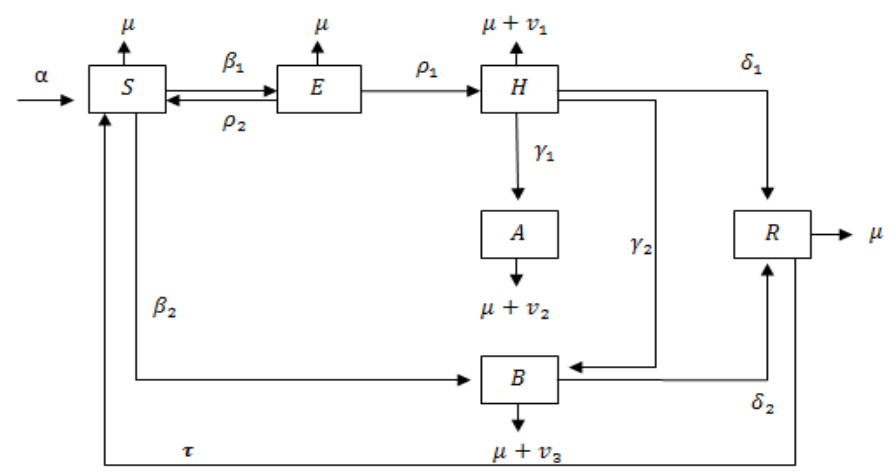

Gambar 1 : Kompartemen Penyebaran Penyakit Akibat Asap Kebakaran Hutan

Diagram alir pada Gambar 1, menjelaskan bahwa dalam membangun model, populasi manusia dibagi menjadi 6 subpopulasi yaitu: Sub populasi manusia rentan $S(t)$, Subpopulasi Exposed $E(t)$, Subpopulasi terinfeksi ISPA $\mathrm{H}(\mathrm{t})$, Subpopulasi terinfeksi Asma $\mathrm{A}(\mathrm{t})$, Subpopulasi terinfeksi Bronchitis $\mathrm{B}(\mathrm{t})$, Subpopulasi sembuh $\mathrm{R}(\mathrm{t})$. Model matematika dibangun dalam bentuk Sistem Persamaan Diferensial (SPD) tak linier sebagai berikut:

$\frac{\partial s}{\partial t}=\alpha+\tau R+\rho_{2} E-\left(\mu+\beta_{1} H+\beta_{2} B\right) S$

$\frac{\partial E}{\partial t}=\beta_{1} H S-\left(\rho_{1}+\mu+\rho_{2}\right) E$

$\frac{\partial H}{\partial t}=\rho_{1} E-\left(\gamma_{1}+\gamma_{2}+\delta_{1}+\mu+v_{1}\right) H$

$\frac{\partial A}{\partial t}=\gamma_{1} H-\left(\mu+v_{2}\right) A$

$\frac{\partial B}{\partial t}=\beta_{2} S B+\gamma_{2} H-\left(\mu+v_{3}+\delta_{2}\right) B$

$\frac{\partial R}{\partial t}=\delta_{1} H+\delta_{2} B-(\mu+\tau) R$

\subsection{Menentukan Titik Kritis}

Titik kritis diperoleh dengan memandang persamaan (1) - (6) dalam keadaan stagnan atau tidak terdapat perubahan dalam populasi sebagai berikut:

$\frac{d S}{d t}=0, \frac{d E}{d t}=0, \frac{d H}{d t}=0, \frac{d A}{d t}=0, \frac{d B}{d t}=0, \frac{d R}{d t}=0$

Sehingga diperoleh dua titik kritis. Titik kritis pertama yang menyatakan populasi bebas penyakit yang diekspresikan sebagai $T_{1}=\left(\frac{\alpha}{\mu}, 0,0,0,0,0\right)$. Titik kritis kedua yang menyatakan keendemikan penyakit akibat asap kebakaran hutan, diekspresikan sebagai $T_{2}=$ $\left(S^{*}, E^{*}, H^{*}, A^{*}, B^{*}, R^{*}\right)$ dengan: 
$S^{*}=\frac{\mu+v_{3}+\delta_{2}}{\beta_{2}}, E^{*}=0, H^{*}=0, A^{*}=0, B^{*}=\frac{-\left(\mu\left(\mu+v_{3}+\delta_{2}\right)-\beta_{2} \alpha\right)(\mu+\tau)}{\beta_{2}\left(\mu^{2}+\mu v_{3}+\mu \delta_{2}+\mu \tau+\tau v_{3}\right)}$, dan $R^{*}=\frac{-\delta_{2}\left(\mu^{2}+\mu v_{3}+\mu \delta_{2}-\alpha \beta_{2}\right)}{\beta_{2}\left(\mu^{2}+\mu v_{3}+\mu \delta_{2}+\mu \tau+\tau v_{3}\right)}$

Eksistensi titik kritis $T_{2}$ yang menggambarkan keendemikan penyakit akibat asap kebakaran hutan dipenuhi untuk syarat berikut:

$$
\beta_{2}>\frac{\mu\left(\mu+v_{3}+\delta_{2}\right)}{\alpha}
$$

\subsection{Menentukan Bilangan Reproduksi Dasar}

Bilangan reproduksi dasar didapatkan dengan membangun matriks yang menunjukkan rata-rata jumlah individu terinfeksi baru dengan metode Next Generation Matrix. Ditentukan suatu transformasi yang menghimpun subpopulasi-subpopulasi yang terinfeksi sebagai $\boldsymbol{x}=$ $(E, H, B)^{T}$, maka persamaan SPD pada persamaan (1) - (6) dapat ditulis sebagai $\frac{d x}{d t}=F(\boldsymbol{x})-$ $V(\boldsymbol{x})$ dengan $F(x)$ adalah matriks transmisi $F$, yaitu matriks yang berisi laju infeksi individu baru karena kontak, dan $V(\boldsymbol{x})$ adalah matriks transisi $V$, yaitu matriks yang berisi laju transfer masuk dan keluar subpopulasi terinfeksi sebagai berikut :

$F(\boldsymbol{x})=\left[\begin{array}{c}\beta_{1} H S \\ 0 \\ \beta_{2} S B\end{array}\right], V(\boldsymbol{x})=\left[\begin{array}{c}\left(\rho_{1}+\mu+\rho_{2}\right) E \\ \left(\gamma_{1}+\gamma_{2}+\delta_{1}+\mu+v_{1}\right) I_{I}-\rho_{1} E \\ \left(\mu+v_{3}+\delta_{2}\right) I_{B}-\gamma_{2} I_{I}\end{array}\right]$

Kemudian dibangun matriks $T(\boldsymbol{x})$ dan $E(\boldsymbol{x})$ yaitu matriks Jacobian dari $F(\boldsymbol{x})$ dan $V(\boldsymbol{x})$ yang dievaluasi di titik kritis bebas asap kebakaran hutan $T_{1}=\left(\frac{\alpha}{\mu}, 0,0,0,0,0\right)$, yaitu:

$\mathrm{T}(\boldsymbol{x})=\left[\begin{array}{ccc}0 & \frac{\beta_{1} \alpha}{\mu} & 0 \\ 0 & 0 & 0 \\ 0 & 0 & \frac{\beta_{2} \alpha}{\mu}\end{array}\right]$ dan $\mathrm{E}(\boldsymbol{x})=\left[\begin{array}{ccc}\rho_{1}+\mu+\rho_{2} & 0 & 0 \\ -\rho_{1} & \gamma_{1}+\gamma_{2}+\delta_{1}+\mu+v_{1} & 0 \\ 0 & -\gamma_{2} & \mu+v_{3}+\delta_{2}\end{array}\right]$

Next Generation Matrix didapatkan dari perkalian $\mathrm{T}(\boldsymbol{x})$ dengan invers $\mathrm{E}(\boldsymbol{x})$ sebagai berikut:

$$
\begin{aligned}
\mathrm{T}(x) \mathrm{E}(\boldsymbol{x})^{-1}=\left[\begin{array}{ccc}
0 & \frac{\beta_{1} \alpha}{\mu} & 0 \\
0 & 0 & 0 \\
0 & 0 & \frac{\beta_{2} \alpha}{\mu}
\end{array}\right]\left[\begin{array}{ccc}
\frac{1}{\left(\rho_{1}+\mu+\rho_{2}\right)} & 0 & 0 \\
\frac{\rho_{1}}{\left(\rho_{1}+\mu+\rho_{2}\right)\left(\gamma_{1}+\gamma_{2}+\delta_{1}+\mu+v_{1}\right)\left(\mu+v_{3}+\delta_{2}\right)} & \frac{\left.\rho_{2} \gamma_{2}+\delta_{1}+\mu+v_{1}\right)}{\left(\rho_{1}+\gamma_{2}+\delta_{1}+\mu+v_{1}\right)\left(\mu+v_{3}+\delta_{2}\right)} & \frac{\left.\gamma_{2}+\mu+v_{1}\right)}{\left(\mu+v_{3}+\delta_{2}\right)}
\end{array}\right] \\
\\
\mathrm{T}(\boldsymbol{x}) \mathrm{E}(\boldsymbol{x})^{-1}=\left[\begin{array}{ccc}
\frac{\beta_{1} \alpha \rho_{1}}{\mu\left(\rho_{1}+\mu+\rho_{2}\right)\left(\gamma_{1}+\gamma_{2}+\delta_{1}+\mu+v_{1}\right)} & x & 0 \\
0 & 0 & 0 \\
y & z & \frac{\beta_{2} \alpha}{\mu\left(\mu+v_{3}+\delta_{2}\right)}
\end{array}\right]
\end{aligned}
$$

dimana :

$$
\begin{aligned}
& x=\frac{\beta_{1} \alpha}{\left(\gamma_{1}+\gamma_{2}+\delta_{1}+\mu+v_{1}\right)} \\
& y=\frac{\beta_{2} \alpha \gamma_{2}}{\mu\left(\rho_{1}+\mu+\rho_{2}\right)\left(\gamma_{1}+\gamma_{2}+\delta_{1}+\mu+v_{1}\right)\left(\mu+v_{3}+\delta_{2}\right)} \\
& z=\frac{\beta_{2} \alpha \gamma_{2}}{\left(\gamma_{1}+\gamma_{2}+\delta_{1}+\mu+v_{1}\right)\left(\mu+v_{3}+\delta_{2}\right)}
\end{aligned}
$$


Nilai $R_{0}$ diperoleh dengan menentukan nilai eigen terbesar dari matriks $T(\boldsymbol{x}) \mathrm{E}(\boldsymbol{x})^{-1}$ atau dapat dinyatakan sebagai $R_{0}=\rho\left(T(\boldsymbol{x}) \mathrm{E}(\boldsymbol{x})^{-1}\right)$, sehingga dari persamaan (9) diperoleh $R_{0 H}\left(R_{0}\right.$ untuk penyakit ISPA) dan $R_{0 B}\left(R_{0}\right.$ untuk penyakit Bronchitis) sebagai berikut:

$$
\begin{aligned}
R_{0 H} & =\frac{\beta_{1} \alpha \rho_{1}}{\mu\left(\rho_{1}+\mu+\rho_{2}\right)\left(\gamma_{1}+\gamma_{2}+\delta_{1}+\mu+v_{1}\right)} \\
R_{0 B} & =\frac{\beta_{2} \alpha}{\mu\left(\mu+v_{3}+\delta_{2}\right)}
\end{aligned}
$$

Jika $R_{0 H}$ dan $R_{0 B}$ pada persamaan (10) dan (11) bernilai lebih dari satu maka penyebaran penyakit akibat asap kebakaran hutan tidak akan hilang dalam populasi serta menyebabkan kondisi endemik.

\subsection{Analisis Kestabilan}

Titik kritis pertama $\left(T_{1}\right)$ menggambarkan keadaan bebas penyakit akibat asap kebakaran hutan. Kestabilan dari titik kritis tersebut ditentukan berdasarkan nilai eigen dari matriks Jacobi yang diperoleh dari persamaan (1) - (6). Mengingat $T_{1}$ bukan titik kritis nol, dilakukan transformasi koordinat sedemikian hingga $T_{1}$ menjadi titik kritis nol. Evaluasi matriks Jacobi dititik $(0,0,0,0,0,0)$ memberikan persamaan karakteristik dalam $\lambda$ sebagai berikut:

$(-\mu-\tau-\lambda)(-\mu-\lambda)\left(-\mu-v_{2}-\lambda\right)\left(-\alpha \beta_{2}+\mu^{2}+\mu v_{3}+\mu \delta_{2}+\mu \lambda\right)\left(a_{0} \lambda^{2}+a_{1} \lambda^{1}+a_{2} \lambda^{0}\right)=0$

Persamaan karakteristik tersebut memberikan nilai eigen $\lambda_{1}=-(\mu+\tau), \lambda_{2}=-\mu, \lambda_{3}=$ $-\left(\mu+v_{2}\right)$ yang bernilai negatif. Adapun $\lambda_{4}$ bernilai negatif bila $R_{0 B}<1$. Nilai eigen lainnya dari persamaan (12) dianalisis dengan menggunakan kriteria Routh-Hurwitz. Sehingga diperoleh Tabel Routh-Hurwitz untuk persamaan tersebut adalah sebagai berikut:

Tabel 1 : Tabel Routh-Hurwitz

$$
\begin{array}{ccc}
\lambda^{2} & a_{0} & a_{2} \\
\lambda^{1} & a_{1} & 0 \\
\lambda^{0} & b_{1}=a_{2} &
\end{array}
$$

dengan:

$a_{0}=\mu$

$a_{1}=\left(\mu \gamma_{1}+2 \mu^{2}+\mu \delta_{1}+\mu v_{1}+\rho_{1} \mu+\mu \gamma_{2}+\rho_{2} \mu\right) \mu$

$a_{2}=\left(\mu\left(\mu^{2}+\mu \delta_{1}+\mu \gamma_{1}+\mu \rho_{1}+\mu \beta_{2}+\mu \gamma_{2}+\mu v_{1}+\rho_{1} \delta_{1}+\rho_{2} \delta_{1}+\rho_{1} \gamma_{1}+\rho_{1} \gamma_{2}+\rho_{1} v_{1}+\rho_{2} \gamma_{1}+\right.\right.$ $\left.\left.\rho_{2} \gamma_{2}+\rho_{2} v_{1}\right)\right)-\alpha \rho_{1} \beta_{1}$

Nilai $\mu>0$ memberi jaminan bagi $a_{0}>0$ dan $a_{1}>0$ dipenuhi karena $\alpha, \beta_{1}, \beta_{2}, \rho_{1}, \rho_{2}, \gamma_{1}, \gamma_{2}$, $\delta_{1}, \delta_{2}, \mu, v_{1}, v_{2}, v_{3}, \tau \geq 0$. Sedangkan $\alpha_{2}>0$ dipenuhi bila:

$\left(\mu\left(\mu^{2}+\mu \delta_{1}+\mu \gamma_{1}+\mu \rho_{1}+\mu \rho_{2}+\mu \gamma_{2}+\mu v_{1}+\rho_{1} \delta_{1}+\rho_{2} \delta_{1}+\rho_{1} \gamma_{1}+\rho_{1} \gamma_{2}+\rho_{1} v_{1}+\rho_{2} \gamma_{1}+\rho_{2} \gamma_{2}+\rho_{2} v_{1}\right)\right)-$ $\alpha \rho_{1} \beta_{1}>0$ yang memberikan :

$$
\begin{gathered}
\mu\left(\rho_{1}+\mu+\rho_{2}\right)\left(\gamma_{1}+\gamma_{2}+\delta_{1}+\mu+v_{1}\right)>\alpha \rho_{1} \beta_{1} \\
\Rightarrow \quad \frac{\alpha \rho_{1} \beta_{1}}{\mu\left(\rho_{1}+\mu+\rho_{2}\right)\left(\gamma_{1}+\gamma_{2}+\delta_{1}+\mu+v_{1}\right)}<1
\end{gathered}
$$




$$
\Rightarrow R_{o H}<1
$$

Disimpulkan bahwa $T_{1}=\left(\frac{\alpha}{\mu}, 0,0,0,0,0\right)$ akan stabil asimtotik lokal jika $R_{0 B}<1, R_{0 H}<1$. Hal ini mengindikasikan kondisi populasi yang bebas dari penyakit akibat asap kebakaran hutan.

Titik kritis kedua $\left(T_{2}\right)$ menggambarkan keendemikan penyakit yang diekspresikan sebagai $T_{2}=\left(S^{*}, E^{*}, H^{*}, A^{*}, B^{*}, R^{*}\right)$. Kestabilan titik kritis tersebut dianalisis dengan matriks Jacobi. Mengingat $T_{2}$ bukan titik kritis nol, dilakukan transformasi koordinat sedemikian hingga $T_{2}$ menjadi titik kritis nol. Evaluasi matriks Jacobi di titik $(0,0,0,0,0,0)$ memberikan persamaan karakterisitik dalam $\lambda$ sebagai berikut:

$\left(-\mu-v_{2}-\lambda\right)\left(a_{0} \lambda^{3}+a_{1} \lambda^{2}+a_{2} \lambda^{1}+a_{3} \lambda^{0}\right)\left(a_{4} \lambda^{2}+a_{5} \lambda^{1}+a_{6} \lambda^{0}\right)=0$

Persamaan karakteristik tersebut memberikan nilai eigen $\lambda_{1}=-\left(\mu+v_{2}\right)$ yang bernilai negatif. Nilai-nilai eigen $\lambda_{2}, \lambda_{3}$, dan $\lambda_{4}$ yang diperoleh dari polynomial berderajat 3 (tiga) dalam $\lambda$ pada persamaan (13) dianalisis dengan Tabel Routh-Hurwitz sebagai berikut:

Tabel 2 : Tabel Routh-Hurwitz

$$
\begin{array}{ccc}
\lambda^{3} & a_{0} & a_{2} \\
\lambda^{2} & a_{1} & a_{3} \\
\lambda^{1} & b_{1} & 0 \\
\lambda^{0} & b_{3}=a_{3} & 0
\end{array}
$$

dengan:

$$
\begin{aligned}
& a_{0}=1 \\
& a_{1}=3 \mu+(B-S) \beta_{2}+\delta_{2}+\tau+v_{3} \\
& a_{2}=3 \mu^{2}+\left((2 B-2 S) \beta_{2}+2 \tau+2 v_{3}+2 \delta_{2}\right) \mu+\left((B-S) \tau+B\left(\delta_{2}+v_{3}\right)\right) \beta_{2}+\tau\left(\delta_{2}+v_{3}\right) \\
& a_{3}=\mu^{3}+\left((B-S) \beta_{2}+\tau+v_{3}+\delta_{2}\right) \mu^{2}+\left(\left((B-S) \tau+B\left(\delta_{2}+v_{3}\right)\right) \beta_{2}+\tau\left(\delta_{2}+v_{3}\right)\right) \mu+\beta_{2} B v_{3} \tau \\
& b_{1}=\frac{a_{1} \cdot a_{2}-a_{0} \cdot a_{3}}{a_{1}}
\end{aligned}
$$

Berdasarkan kriteria kestabilan Routh-Hurwitz, titik kritis $\mathrm{T}_{2}$ akan stabil asimtotik lokal jika koefisien persamaan karakteristik bernilai positif . Mengingat $a_{0}>0$ maka kriteria RouthHurwitz dipenuhi bila $a_{1}$ dan $b_{1}$ positif, yaitu $a_{1}$ bernilai positif dengan syarat $R_{0 B}{ }^{*}<R_{0 B}<1$ dengan $R_{0 B}{ }^{*}=\frac{\mu^{2}+\left(v_{3}+\delta_{2}+\tau\right) \mu+\tau v_{3}}{\mu^{2}+\left(v_{3}+\delta_{2}+\tau+1\right) \mu+\left(v_{3}+1\right) \tau}$ dan $b_{1}$ bernilai positif mengingat koefisien-koefisien dari polinomial $\mu$ positif, maka $a_{1} \cdot a_{2}-a_{3}$ adalah bernilai positif.

Sedangkan nilai eigen lainnya yaitu $\lambda_{5}$ dan $\lambda_{6}$ yang diperoleh dari polynomial berderajat 2 (dua) dalam $\lambda$ pada persamaan (13) dianalisa dengan Tabel Routh-Hurwitz sebagai berikut:

Tabel 3 : Tabel Routh-Hurwitz

$$
\begin{array}{ccc}
\lambda^{2} & a_{4} & a_{6} \\
\lambda^{1} & a_{5} & 0 \\
\lambda^{0} & a_{6} &
\end{array}
$$

dengan :

$a_{4}=1$ 
$a_{5}=\left(\gamma_{1}+2 \mu+\rho_{2}+\delta_{1}+v_{1}+\rho_{1}+\gamma_{2}\right)$

$a_{6}=\left(\mu^{2}+\gamma_{1}+\gamma_{2}+\rho_{2}+\delta_{1}+v_{1}+\rho_{1}\right) \mu+\rho_{1}\left(\gamma_{1}+\gamma_{2}+\delta_{1}+v_{1}-\beta_{1} S\right)$

Karena $a_{4}$ dan $a_{5}$ bernilai positif maka kolom pertama tabel Routh-Hurwitz tidak memiliki perubahan tanda jika $a_{6}$ bernilai positif, yaitu jika $\frac{\beta_{1}}{\beta_{2}}<\frac{\left(\gamma_{1}+\gamma_{2}+\delta_{1}+v_{1}\right)}{\left(\mu+v_{3}+\delta_{2}\right)}$

\subsection{Simulasi}

Dinamika penyebaran penyakit yang disebabkan oleh asap kebakaran hutan menggunakan model yang telah dikontruksi pada persamaan (1) - (6) disimulasikan menggunakan nilai-nilai parameter dan nilai awal untuk tiap subpopulasi yang dinyatakan pada Tabel 4 dan Tabel 5.

Tabel 4 : Nilai Parameter Komputasi

\begin{tabular}{|c|c|c|}
\hline Parameter & Nilai & Sumber \\
\hline$a$ & $\begin{array}{c}\text { Ditentukan dengan syarat } \\
\text { Eksis dan stabil }\end{array}$ & Asumsi \\
\hline$\beta_{1}$ & 0,8 & Asumsi \\
\hline$\beta_{2}$ & 0,5 & Asumsi \\
\hline$\rho_{1}$ & 0,07 & 1 \\
\hline$\rho_{2}$ & 0,03 & Masa Inkubasi \\
\hline$\gamma_{1}$ & 0,03 & Asumsi \\
\hline$\gamma_{2}$ & 0,033 & Asumsi \\
\hline$\mu$ & 0,0000421 & 1 \\
\hline$v_{1}$ & 0,3 & Sife Time \\
\hline$v_{2}$ & 0,08 & WHOndayani, 2007 \\
\hline$v_{3}$ & 0,1 & WHO \\
\hline$\delta_{1}$ & 0,04 & Sojaja, S, 2001 \\
\hline$\delta_{2}$ & 0,01 & Asumsi \\
\hline$\tau$ & 0,03 & \\
\hline & & Soegito, 2004 \\
\hline & & \\
\hline
\end{tabular}

Tabel 5 : Nilai awal untuk tiap subpopulasi

\begin{tabular}{|c|c|c|}
\hline Subpopulasi & Jumlah/orang & Sumber \\
\hline S & 158 & Fikri Faisal,dkk, 2012 \\
\hline E & 144 & Fikri Faisal,dkk, 2012 \\
\hline H & 128 & Fikri Faisal,dkk, 2012 \\
\hline A & 38 & Fikri Faisal,dkk, 2012 \\
\hline B & 44 & Fikri Faisal,dkk, 2012 \\
\hline R & 50 & Asumsi \\
\hline
\end{tabular}


Dengan menggunakan perangkat lunak Maple 13 didapatkan dinamika tiap subpopulasi dapat digambarkan sebagai berikut:

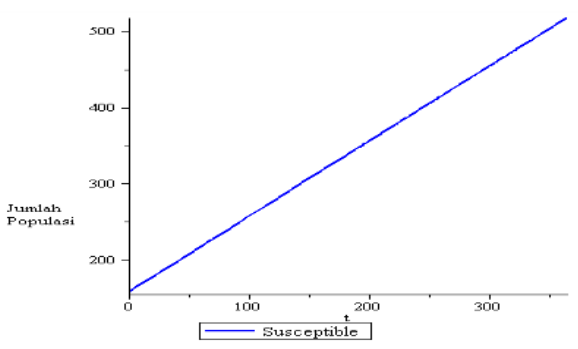

(a)

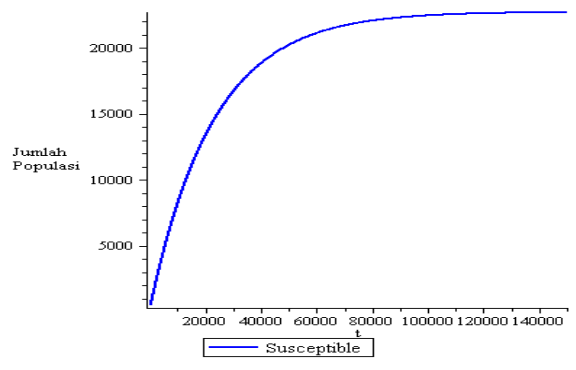

(b)

Gambar 2 : (a) Subpopulasi Manusia Rentan $0 \leq t \leq 365$ dan (b) Subpopulasi Manusia Rentan $365 \leq t \leq 150000$

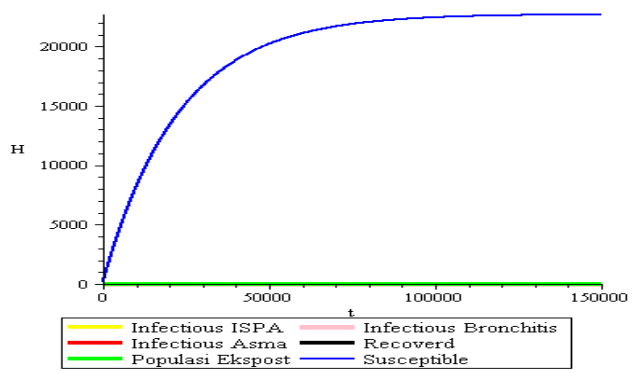

Gambar 3 : Simulasi Kondisi Bebas Penyakit Saat $R_{0}=0<1$

Dalam hal syarat eksistasi dan kestabilan titik kritis dipenuhi, kurva berwarna biru pada Gambar 2, Gambar 3 dan Gambar 4, memperlihatkan bahwa subpopulasi rentan akan mengalami peningkatan. Bertambahnya subpopulasi ini dikarenakan besarnya tingkat rekruitmen yang diberikan. Anggota subpopulasi ini akan terus meningkat hingga mencapai 22.560 orang di saat $t=328$ tahun dan bernilai tetap sebanyak 22.628 orang setelah $t=356$ tahun. Sedangkan subpopulasi lainnya bernilai 0 untuk setiap $t$ yang menggambarkan populasi dalam kondisi terbebas dari asap kebakaran hutan karna hanya populasi rentan yang eksis. 


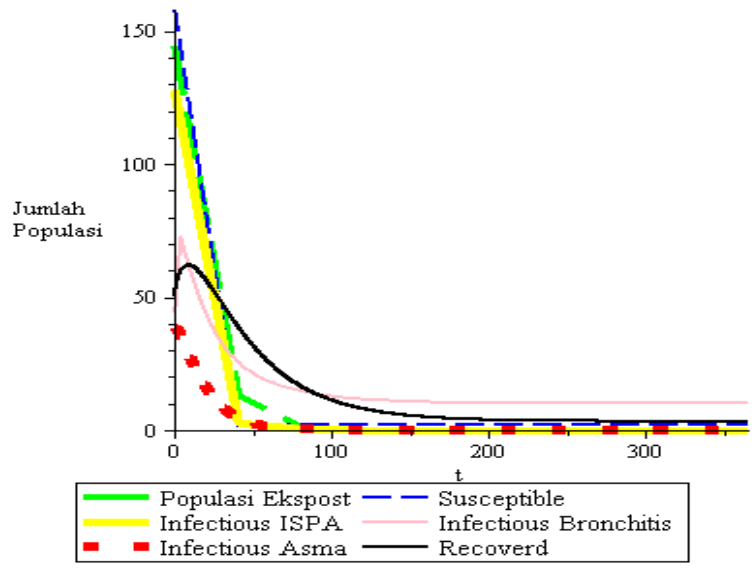

Gambar 4 : Kurva Simulasi endemik penyakit Saat $R_{0}=10792.67349>1$ dan $0 \leq t \leq 365$

Simulasi subpopulasi pada gambar 5 menunjukkan keadaan endemik penyakit akibat asap kebakaran hutan. Pada Gambar 5 terlihat ada 6 subpopulasi yaitu subpopulasi rentan, subpopulasi Exposed, subpopulasi ISPA, subpopulasi Asma, subpopulasi Bronchitis dan subpopulasi Recovered dilakukan berdasarkan syarat eksis dan stabil. Terlihat bahwa semua keadaan subpopulasi tersebut akan mengalami penurunan yang disebabkan oleh penyakit dan keadaan sembuh dari subpopulasi tersebut.

\subsection{Pembahasan}

Simulasi untuk kondisi endemik penyakit akibat asap kebakaran hutan dilakukan berdasarkan syarat eksis dan stabil. Pada Gambar 5 , terlihat laju pertumbuhan subpopulasi rentan yang awalnya 158 orang menurun menjadi 1 orang pada hari ke-33 yang disebabkan karena adanya laju infeksi ISPA dan Bronchitis yang menginfeksi subpopulasi rentan. Keadaan subpopulasi rentan perlahan akan naik yang disebabkan karena adanya subpopulasi yang sembuh dan kemudian menjadi subpopulasi rentan kembali, sehingga subpopulasi rentan berjumlah 2 orang pada hari ke-132 dan bernilai tetap hingga hari ke-300. Ini berarti, pada subpopulasi tersebut sudah tidak ada lagi bertambahan. Kemudian laju pertumbuhan subpopulasi Eksposed awalnya 144 orang akan mengalami penurunan. Hal ini disebabkan karena perpindahan subpopulasi rentan ke subpopulasi eksposed lebih besar di bandingkan perpindahan subpopulasi eksposed ke subpopulaasi rentan dan juga adanya laju infeksi ISPA dan kematian alami. Laju pertumbuhan subpopulasi ini akan bernilai 0 pada hari ke-130 dan bernilai tetap hingga hari ke-300.

Kurva simulasi subpopulasi ISPA pada simulasi endemik penyakit menunjukkan laju pertumbuhan subpopulasi ISPA mengalami penurunan. Hal ini disebabkan karena adanya laju kematian subpopulasi ISPA, juga adanya subpopulasi ISPA yang berpindah menjadi subpopulasi terinfeksi asma dan bronchitis, serta adanya subpopulasi ISPA yang sembuh dan keadaan tersebut lebih besar dari laju pertambahan subpopulasi terinfeksi ISPA. Laju 
pertumbuhan subpopulasi ini akan bernilai 0 pada hari ke-106 dan bernilai tetap hingga hari ke-300. Laju pertumbuhan subpopulasi asma akan mengalami penurunan dari 38 orang menjadi 3 orang pada hari ke-60 kemudian akan mengalami penurunan kembali sehingga bernilai 0 pada hari ke-130 dan bernilai tetap hingga hari ke-300. Hal ini disebabkan karena laju kematian asma yang ditambahkan dengan kematian alami lebih besar di bandingkan dengan infeksi dari subpopulasi terinfeksi ISPA yang menginfeksi subpopulasi asma.

Gambar 5 menunjukan laju pertumbuhan Subpopulasi bronchitis yang awalnya 44 orang meningkat sebanyak 72 orang pada hari ke-2. Hal ini disebabkan karena adanya subpopulasi rentan yang masuk ke subpopulasi bronchitis dan adanya laju perpindahan subpopulasi terinfeksi ISPA ke subpopulasi terinfeksi bronchitis. Kemudian laju subpopulasi ini akan menurun karena adanya laju kematian yang di sebabkan oleh subpopulasi bronchitis dan di tambahkan dengan kematian alami serta adanya laju pemulihan subpopulasi terinfeksi Bronchitis. Laju pertumbuhan subpopulasi ini akan bernilai tetap sebanyak 10 orang setelah hari ke-180. Kemudian untuk yang terakhir kurva simulasi subpopulasi Recovered/Sembuh menunjukkan laju pertumbuhan yang awalnya 50 orang akan meningkat sebanyak 58 orang di hari ke-6 yang di sebabkan karena adanya laju pemulihan subpopulasi terinfeksi ISPA dan laju pemulihan subpopulasi terinfeksi Bronchitis. Subpopulasi ini akan menurun hingga mencapai 3 orang pada hari ke-137 dan bernilai tetap hingga mencapai hari ke-300. Hal ini disebabkan karena adanya laju kematian alami dan laju perubahan individu yang sembuh ke subpopulasi yang rentan.

\section{KESIMPULAN}

Berdasarkan penelitian yang telah dilakukan, diambil kesimpulan sebagai berikut:

1. Dari analisis yang dilakukan di setiap titik kritis, didapatkan syarat kestabilan pada masingmasing titik kritis, yaitu $T_{1}$ stabil jika $R_{0 H}<1$ dan $R_{0 B}<1$ dengan batas ambang kestabilan yang diekspresikan sebagai:

$R_{0 H}=\frac{\beta_{1} \alpha \rho_{1}}{\mu\left(\rho_{1}+\mu+\rho_{2}\right)\left(\gamma_{1}+\gamma_{2}+\delta_{1}+\mu+v_{1}\right)} \quad$ dan $\quad R_{0 B}=\frac{\beta_{2} \alpha}{\mu\left(\mu+v_{3}+\delta_{2}\right)}$

Kondisi endemik $\left(T_{2}\right)$ akan stabil asimtotik saat $R_{0 B}{ }^{*}<R_{0 B}<1$ dan $\quad \frac{\beta_{1}}{\beta_{2}}<\frac{\left(\gamma_{1}+\gamma_{2}+\delta_{1}+v_{1}\right)}{\left(\mu+v_{3}+\delta_{2}\right)}$

Dengan $R_{0 B}{ }^{*}=\frac{\mu^{2}+\left(v_{3}+\delta_{2}+\tau\right) \mu+\tau v_{3}}{\mu^{2}+\left(v_{3}+\delta_{2}+\tau+1\right) \mu+\left(v_{3}+1\right) \tau}$

2. Kondisi bebas penyakit yang menggambarkan terbebasnya populasi dari asap kebakaran hutan karena tercapai dalam waktu yang sangat lama. Sedangkan kondisi endemik tercapai dalam waktu yang singkat. Hal ini menjelaskan bahwa penyakit akibat asap kebakaran hutan tidak mudah untuk diatasi. 


\section{DAFTAR PUSTAKA}

[1] Brauer M, Health Impact of Biomass Air Pollution. WHO. [cited 2007 Nov 4]. Available from: http//www.firesmokeheealth.org. 3.

[2] D Schwela, Health Guidelines for Vegetation Fire Events, The WHO-unepwmo, Dec 4th 2001, Department of Protection of the Human Environment, Occupational and Evironmental, 2.

[3] Hudoyo, A, Penatalaksanaan Asma \& PPOK Pada Orang Dewasa berdasar Pedoman GINA (Global Initiative for Asthma) \& GOLD (Global Initiative for Chronic Obstructive Lung Disease), 2014, Dept Pulmonologi \& IImu Kedokteran Respirasi FKUI/SMF Paru RS. Persahabatan - Jakarta Timur, 1.

[4] Ikawati, Z. Penyakit Sistem Pernafasan dan Tata laksana Terapinya. Bursa IImu, 2011, Yogyakarta, 3.

[5] National Center for Health Statistics, International Classification of Disease, Tenth Revision (ICD-10), 2000, http://www.cdc.gov/nchs/about/major/dvs/icd10des. htm. [20 November 2015].

[6] Oktaviani, V, A, Hubungan Antara Sanitasi Fisik Rumah dengan Kejadian ISPA pada Balita, Universitas Muhammadiyah, 2009, Surakarta.

[7] Soegito, Pengobatan Bronkitis Kronik Eksaserbasi Akut Dengan Ciprofloxacin Dibandingkan Dengan Co Amoxyclav, Fakultas Kedokteran, 2004, Universitas Sumatera Utara.

[8] Suhandayani, I, Faktor-Faktor yang Berhubungan dengan Kejadian ISPA pada Balita. Puskesmas Pati, 2007, Semarang

[9] Survei Kesehatan Rumah Tangga, Badan Penelitian dan Pengembangan (Litbang), Depkes RI, 1992, Jakarta. 